\title{
The Euro and Stock Markets in Hungary, Poland, and UK
}

\author{
Tomoe Moore \\ Coventry University
}

\begin{abstract}
This paper aims to empirically investigate the effect of the euro on stock markets for Hungary, Poland and the UK, and also the co-movement of the stock prices with the euro-zone using the daily stock price indices. The result reveals that in order to develop the emerging stock markets, exchange rates should appreciate for Hungary, whereas they should depreciate for Poland. Furthermore, evidence of cointegration between the relative stock prices against Germany and exchange rates suggests that participating in the European Monetary Union may, ceteris paribus, stabilise the stock markets for these non-euro member states.
\end{abstract}

- JEL classification: F02, F31, G1, G3

- Keywords: Stock prices, Exchange rates, Cointegration, Poland, Hungary, UK, GARCH

\section{Introduction}

It is generally argued that the relationship between exchange rates and stock prices has important implications. Uncovered Interest rate Parity (UIP) suggests that the expectations of relative currency values influence the levels of domestic and foreign interest rates. This, in turn, affects the cost of capital, thereby profitability of a firm, and consequently the present value of the firm may change. Portfolio approaches suggest that in the international diversification of shares,

\footnotetext{
*Corresponding address: Tomoe Moore, Coventry Business School, Coventry University, Coventry, CV1 5FB, United Kingdom, Phone: 0044247688 7414, Fax: 0044247688 8400, E-mail: T. Moore@ coventry.ac.uk

(C2007-Center for International Economics, Sejong Institution, All Rights Reserved.
} 
changes in exchange rates alter stock returns, hence this leads to changes in stock prices. The interaction between the two variables can also arise through the implications on price competitiveness or input costs. These suggest that exchange rates may play a significant role in the movement of stock prices. There is a number of empirical works examining the relationship for various countries. The existing literature tends to concentrate on the causal relationship, and so Grangercausality tests are quite often conducted. Among studies, see, for example, Abdalla and Murinde (1997) and Smyth and Nandha (2003) for South East Asian countries using monthly and daily data respectively. Ajayi et al (1998) studied extensively developed and emerging markets using daily data. They tend to find that exchange rates granger-cause stock prices, however, they fail to find cointegration relationshipo between the two variables.

This paper aims to empirically investigate the effect of the euro on stock markets for Hungary, Poland and the UK, and also the co-movement of the stock prices with the euro-zone. This article focuses on the link between the stock prices relative to German ones and changes in exchange rates against the euro. The UK market is considered to be a benchmark one. Using the daily stock price indices for the period from $4^{\text {th }}$ January 1999 to $26^{\text {th }}$ January, 2005 with the first observation being the beginning of the euro currency, a cointegration relationship is examined. The dynamic error correction model is then analysed in a VAR-GARCH framework ${ }^{1}$.

The study differs from the existing literature in three ways. First, there is hardly any empirical research on the relationship between stock prices and exchange rates relating to the markets in the transition economies of Eastern Europe. In the posteuro period, empirically the euro's effect on the stock market in the non-euro zone is an important question, especially for new European Union (EU) members in the process of economic integration within the EU. In emerging countries it is

'The GARCH model is developed by Engle (1982) and later generalised by Bollerslev (1986). Since the dynamic error correction model is specified in the GARCH model, the term of a 'VAR-GARCH' is used. See, for example, Koutmos (1992) and Westermann (2004) applied the VAR-GARCH model to modelling stock prices. Westermann (2004) empirically examined the co-movement of European stock markets, in order to investigate a distinct behaviour in stock returns before and after the introduction of the euro for the current euro-zone members. It is found that feedback trading among the euro-zone disappeared in the post-euro period indicating a shift in the stock markets. This suggests that the Euro affects stock markets, providing the usefulness of our study. Whilst Westermann (2004) concentrates on the study within the euro-zone with the stock returns of an EU country as a function of the lagged stock returns of the own and other EU member states, this paper examines the co-movement of stock markets between the non euro-zone vis-a-vis the largest economy, i.e. Germany, in the euro-zone. 
considered that stock prices and exchange rates have a crucial role in affecting the development of stock markets with the expanding corporate sectors with listed firms and the growing tradable sector (Abdalla and Murinde, 1997).

The second contribution is that, prior to cointegration tests, structural breakpoint tests are conducted year by year. During the sample period, Poland and Hungary were in the process of converging towards the economies in the EU, and accession to the EU was achieved in May 2004. The potential structural breaks in the stock and foreign exchange markets may not be trivial. In much of the existing literature, potential structural breaks are overlooked. For example, Smyth and Nandha, (2003) for the study of South Asian countries for the period 1995-2001, fail to take into account currency turbulence in South-East Asian markets and Russian financial turmoil in 1997, when many Asian countries had experienced a serious economic crisis and their currencies fell by $50 \%$ or more against the dollar. See also Bahmani-Oskooee and Sohrabian (1992), Ratner (1993), Granger, Huang and Yang (2000), Nieh and Lee (2001). None of the literature deals with structural shifts. The failure to obtain a cointegration relationship may be due to omitted variables. Empirical evidence of Shamsuddin and Kim (2003) reveals that this may be the case: a cointegration relationship is found between the two variables before the Asian crisis for Australia, Japan and the US, however, it is not found in the post-Asian crises period.

The research in this paper is carried out with daily data, which may be more appropriate for this type of study because a sampling frequency of less than one day may introduce spurious statistical significance (Ajayi et al. 1998). The third contribution is that given daily data, the dynamic error correction model is specified by a VAR-GARCH model to investigate the short-run intertemporal relationship. This is important as more efficient estimators can be obtained if heteroskedasticity in the errors is handled properly. Although the literature on conditional heteroskedasticity of stock returns in the univariate GARCH model is fairly voluminous, this is largely neglected in investigating the relationship between daily stock price indices and exchange rates in the existing literature.

Analysing the relationship between the relative stock prices and changes in exchange rates provides important policy implications for the non-euro zone member states in two ways. First, it has an implication in the conduct of exchange rate policy. Empirical evidence reveals that the euro influences the stock markets in Hungary, Poland and the UK. A negative long-run relationship between the relative stock prices and exchange rates is found for Hungary implying that the stock 
market outperforms the German stock market when the currency appreciates against the euro. The finding of a positive relationship for Poland and the UK suggests that the stock markets outperform the German market when the currency depreciates. These results imply that in order to develop emerging stock markets, exchange rates should appreciate for Hungary, whereas they should depreciate for Poland. Second, it gives insight into joining the European Monetary Union (EMU) with respect to the effect on stock markets. Accession to EMU results in a country losing its autonomy over exchange rate policy, and a potential shift in the stock market may emerge ${ }^{2}$. Evidence of cointegration for all three countries suggests that the introduction of the euro may, ceteris paribus, stabilise the stock markets for Poland, Hungary and the UK, and that the integration with the euro-zone may exert a favourable effect on corporate finance.

This paper is organised as follows. In Section 2, a model for estimation is specified. In section 3, the tests of unit root, structural breaks and cointegration are conducted. In Section 4 and 5, the long-run model and dynamic error correction model with the VAR-GARCH specification are presented respectively. Conclusions are found in section 6 .

\section{Model and Data}

The relative stock price between the domestic and foreign countries is defined as given by (Malliaropulos, 1998),

$$
\lambda_{t} \equiv s_{t}-s_{t}^{*}-e x_{t}
$$

$s$ denotes the domestic stock price indices, and $\mathrm{s}^{*}$ denotes the foreign stock price indices, and ex denotes a number of domestic currency per unit of foreign currency. All variables are in logarithmic forms. $\lambda$ implies the number of domestic shares in exchange for one foreign share (Malliaropulos, 1998). The equation suggests that the price differential between the domestic and foreign stock markets equals the change in the relative stock price. This is conceptually equivalent to the Uncovered Interest rate Parity (UIP) applied to stock prices with a risk premium. Unlike the normal UIP, which applies to riskless investments, the stock return is stochastic. The risk premium, therefore, contains both foreign exchange risk and relative equity risk components. Re-writing this equation, we have,

${ }^{2}$ Baily et al. (2003) empirically find that the exchange rate regime changes are often associated with the shift in the volatility of stock markets and correlations between the two markets. 


$$
\left(s_{t}-s_{t}^{*}\right) \equiv \lambda+e x_{t}
$$

This states that stock price differentials are equivalent to risk premium and nominal exchange rates. Applying this model to an empirical estimation, we have,

$$
\left(s_{t}-s_{t}^{*}\right) \equiv \alpha+\beta e x_{t}+u_{t}
$$

The domestic stock prices relative to those of Germany are defined as $s-s^{*}$ where $s$ denotes the domestic stock price indices (i.e. Hungary, Poland and the UK) and $s^{*}$ denotes the German stock price indices. Nominal exchange rates, ex is defined as units of domestic currency per Euro. $u_{t}$ is an error term. The specification is similar to that of Shamsuddin and Kim (2003) ${ }^{3}$. The equation (3) provides insight in meeting the two main objectives of this paper. First, the effect of the euro is directly obtained from the model estimation. Second, the comovement of stock prices between the non-euro zone and Germany is predicted by the existence of cointegration, in that, if cointegration is found between $s-s^{*}$ and $e x$, it is likely that $s$ moves in line with $s^{*}$, when $e x$ is fixed in the introduction of the euro regime for Hungary, Poland and the UK.

The sample period starts from $4^{\text {th }}$ January 1999 to 26 January 2005 (1583 observations of daily data, excluding Saturday and Sunday). Data are all collected from Datastream with the World stock indices for stock prices.

\section{Unit Root, Structural Breakpoint, and Cointegration Tests}

The augmented Dicky Fuller (ADF) test together with Phillips Perron's test are shown in Table 1, which indicates that all data series are characterised as an integrated of order one ${ }^{4}$. The results seem to be supported by the plot of series shown in Appendix 1 in levels and Appendix 2 in first differences.

Prior to Johansen cointegration tests, structural breakpoint tests are conducted. It is argued that structural breaks are a common phenomenon when time-series data span a long time horizon (Bai, 1996), and it is more likely for the long-run

\footnotetext{
${ }^{3}$ Some studies on stock market integration use share prices in local currency or stock returns, and ignore foreign exchange risks (e.g. Ragunathan et al. 1999; Westermann, 2004). A limitation of this approach is that it assumes that movements in stock prices and exchange rates are uncorrelated and investors completely hedge against foreign exchange risks. Shamsuddin and Kim (2003) argue that an investor, with an attempt to diversify a share price risk internationally, is unable to rely on this approach as it ignores the interaction between the exchange rate and stock price.
} 
Table 1. Unit Root tests

\begin{tabular}{lcccc}
\hline & \multicolumn{2}{c}{ ADF test } & \multicolumn{2}{c}{ Phillips-Perron's test } \\
\hline Lungary $\left(\mathrm{s}-\mathrm{s}^{*}\right)$ & $-1.678(5)(\mathrm{t})$ & $-20.566^{*}(4)$ & $-1.581(23)(\mathrm{t})$ & $-42.530^{*}(23)$ \\
Hungary $e x$ & $-2.166(7)$ & $-17.661^{*}(6)$ & $-2.509(28)$ & $-41.951^{*}(32)$ \\
Poland $\left(\mathrm{s}-\mathrm{s}^{*}\right)$ & $-0.622(6)$ & $-19.173^{*}(5)$ & $-0.927(20)$ & $-45.499 *(19)$ \\
Poland $e x$ & $-1.438(13)$ & $-10.201^{*}(12)$ & $-1.472(22)$ & $-45.583 *(19)$ \\
UK $\left(\mathrm{s}-\mathrm{s}^{*}\right)$ & $-1.760(18)$ & $-10.964^{*}(11)$ & $-1.627(10)$ & $-45.162^{*}(11)$ \\
UK $e x$ & $-3.274(0)(\mathrm{t})$ & $-15.286^{*}(7)$ & $-3.250(3)(\mathrm{t})$ & $-39.893 *(4)$ \\
\hline
\end{tabular}

$(\mathrm{t})=\mathrm{a}$ deterministic trend is included based on the statistical significance at the $5 \%$ level.

* Significant at the $5 \%$ level with the critical value of 2.863 without trend and 3.413 with trend.

Figures in parenthesis are lag lengths based on Akaike' Information Criterion (AIC) for ADF test and Newey-West Bandwidth for Phillips-Perron test. The maximum lag length for AIC is 24 according to the formula of $\max =12(\mathrm{~T} / 100)^{0.25}$ (Hayashi, 2000).

relationship to be disturbed by various factors. With the sample size of six years in the current study, the time span may be short. However, given the fact that Poland and Hungary are transition economies, it is more likely that the post-Euro period may have generated some shifts. The failure to take into account these shifts, given their presence, may lead to incorrect estimation results. Chow breakpoint tests are, therefore, conducted to determine the structural breaks. Following Bai (1996), break points are chosen at the beginning of each year making a total of five points: $3 / 1 / 2000,1 / 1 / 2001,1 / 1 / 2002,1 / 1 / 2003$ and $1 / 1 / 2004^{5}$. The test is conducted based on the bivariate VAR model to be consistent with the Johansen model specification. The lag lengths are determined by the likelihood ratio (LR) tests while ensuring white noise in error terms. The results shown in Table 2 indicate that data tend to find structural shifts, as is predicted, especially in the stock price $\left(s-s^{*}\right)$ equation for Hungary and in the exchange rate $(e x)$ equation for the UK. The

\footnotetext{
${ }^{4}$ Perron (1989) argues that a unit root test, which does not take account of the structural break in the series will have a very low power. Perron's test allows for a shift in the level and slope of the trend at a predetermined point as the alternative to a unit root process. However, we do not pursue Perron's test on the following grounds: First, without knowing the potential breaks, on a priori, it is difficult to conduct Perron's test for the daily data. Second, the main concern is the breaks in terms of a cointegration relationship. Third, the Phillips Perron's unit root test, which generally has a higher power, being suitable for a large sample size, may be an appropriate approach.

${ }^{5}$ It is argued that for structural change of unknown timing, a researcher has only two choices in testing structural breaks, i) one is to pick an arbitrary candidate breakdate, and ii) to pick a breakdate based on some known feature of the data (Hansen 2001). Our approach is similar to the former. However, rather than picking an arbitrary breakdate, breakpoints are picked up with each being the equal interval of one year over the whole sample period.
} 
Table 2. Structural Breakpoint tests

\begin{tabular}{|c|c|c|c|c|c|c|c|}
\hline Breakpoint & & $\begin{array}{c}\text { Hungary } \\
s-s * \text { (prob.) }\end{array}$ & $\begin{array}{l}\text { Hungary } \\
\text { ex (prob.) }\end{array}$ & $\begin{array}{c}\text { Poland } \\
s-s * \text { (prob.) }\end{array}$ & $\begin{array}{l}\text { Poland } \\
\text { ex (prob.) }\end{array}$ & $\begin{array}{c}\text { UK } \\
\left.s-s^{*} \text { (prob. }\right)\end{array}$ & $\begin{array}{c}\mathrm{UK} \\
\text { ex (prob.) }\end{array}$ \\
\hline \multirow{4}{*}{$1 / 3 / 2000$} & \multirow{2}{*}{ F-stat } & $2.613 *$ & $1.843 *$ & 1.082 & 1.280 & 1.169 & $1.412^{*}$ \\
\hline & & $(0.0003)$ & $(0.019)$ & $(0.340)$ & $(0.122)$ & $(0.221)$ & $(0.048)$ \\
\hline & \multirow{2}{*}{ LR } & $44.752 *$ & $31.702 *$ & 41.453 & 48.931 & 47.255 & $56.928 *$ \\
\hline & & $(0.0002)$ & $(0.016)$ & $(0.283)$ & $(0.091)$ & $(0.171)$ & $(0.032)$ \\
\hline \multirow{4}{*}{$1 / 1 / 2001$} & \multirow{2}{*}{ F-stat } & $2.020^{*}$ & $2.107^{*}$ & 1.198 & $2.161^{*}$ & $1.681^{*}$ & $2.448^{*}$ \\
\hline & & $(0.008)$ & $(0.005)$ & (0.194) & $(0.000)$ & $(0.006)$ & $(0.000)$ \\
\hline & \multirow{2}{*}{ LR } & $34.712 *$ & $36.198 *$ & 45.840 & $81.766 *$ & 67.520 & $97.380 *$ \\
\hline & & $(0.007)$ & $(0.004)$ & $(0.151)$ & $(0.000)$ & $(0.003)$ & $(0.000)$ \\
\hline \multirow{4}{*}{$1 / 1 / 2002$} & \multirow{2}{*}{ F-stat } & $2.018^{*}$ & 1.027 & $1.506^{*}$ & 0.796 & $1.850^{*}$ & $1.538^{*}$ \\
\hline & & $(0.008)$ & $(0.425)$ & $(0.027)$ & $(0.805)$ & $(0.001)$ & $(0.019)$ \\
\hline & \multirow{2}{*}{ LR } & $34.685^{*}$ & 17.737 & $57.429 *$ & 30.596 & $74.153 *$ & $61.894 *$ \\
\hline & & $(0.007)$ & $(0.406)$ & $(0.017)$ & $(0.762)$ & $(0.0005)$ & $(0.011)$ \\
\hline \multirow{4}{*}{$1 / 1 / 2003$} & \multirow{2}{*}{ F-stat } & $1.785^{*}$ & $2.051^{*}$ & 1.026 & 0.728 & 1.276 & $1.579^{*}$ \\
\hline & & $(0.025)$ & $(0.007)$ & $(0.427)$ & $(0.886)$ & $(0.120)$ & $(0.013)$ \\
\hline & \multirow{2}{*}{ LR } & $30.713 *$ & $35.238 *$ & 39.352 & 28.036 & 51.519 & $63.508 *$ \\
\hline & & $(0.021)$ & $(0.006)$ & $(0.365)$ & $(0.856)$ & $(0.086)$ & $(0.008)$ \\
\hline \multirow{4}{*}{$1 / 1 / 2004$} & \multirow{2}{*}{ F-stat } & 0.838 & 1.143 & 0.398 & 0.656 & 0.379 & 0.619 \\
\hline & & $(0.649)$ & $(0.306)$ & (0.999) & $(0.945)$ & (0.999) & $(0.969)$ \\
\hline & \multirow{2}{*}{ LR } & 14.492 & 19.739 & 15.392 & 25.287 & 15.482 & 25.224 \\
\hline & & $(0.632)$ & $(0.287)$ & (0.999) & $(0.928)$ & (0.999) & $(0.957)$ \\
\hline
\end{tabular}

* Significant at the $5 \%$ level. Prob. $=$ Probability values

- The Chow tests are conducted on the VAR model specification with the lag $=8$ for Hungary, and lag $=19$ for the UK. Order of VAR is determined by the likelihood ratio (LR) test criteria, while ensuring white noise for error terms. Poland chooses 1 by the LR test, however order $=18$ is chosen in order to ensure white noise.

- With Chow's breakpoint test, the whole sample period ( $T$ observations) is split into two at each point. Chow's forecast F-statistic is computed as

$F=\frac{\left(R S S_{R}-\left(R S S_{1}+R S S_{2}\right)\right)^{\prime} k}{\left(R S S_{1}+R S S_{2}\right)^{\prime}(T-2 k)}$

where $R S S_{R}$ is the restricted residual sum of squares when the equation is fitted to the whole sample period, $R S S_{1}$ is the residual sum of squares from subsample $i, T$ is the total number of observations, and $k$ is the number of estimated coefficients. The statistic follows F-distribution. If the null is rejected, then there is a structural break at the chosen point.

- The log likelihood ratio (LR) test is based on the comparison of the restricted and unrestricted maximum of the log likelihood function. The LR test has an asymptotic $\chi^{2}$ distribution.

shift dummy is specified in the Johansen cointegration test when data find a significant structural break in either stock price or exchange rate equations.

The general argument of evidence of structural breaks may be that, in the process of the transition from controlled to market-related economies, the transition economies have experienced a rapid expansion in international trade, accompanied with the changing capital structure, while shifting the policy towards the 
integration with the EU. Specifically, in terms of exchange rate arrangements, bands for pegging to a currency basket widened in Hungary in June 2001, whereas a floating system was introduced in Poland in April 2000. These factors may be reflected as the structural breaks. Other factors may include the introduction of the Euro itself. Especially in the case of UK, the evidence of shifts in exchange rates may be due to the emergence of the Euro.

With an inclusion of shift dummies, the model for Johansen's cointegration test is specified as follows (Harris, 1995):

$$
\Delta Y_{t}=\Gamma_{1}+\Delta Y_{t-1}+\ldots+\Gamma_{p-1} \Delta Y_{t-p+1}+\Pi Y_{t-p}+\psi D_{t}+\varepsilon_{t}
$$

where $\varepsilon_{t}, \sim \operatorname{iid}(0, \Sigma), Y=s-s^{*}$, ex and $D=$ shift dummies $^{6} . p$ is the order of VAR, which is consistent with those in the structural break tests. Assuming that there exists a cointegration relationship, then $\Pi=\alpha \beta$ where represents the speed of adjustment to equilibrium, while $\beta$ is a matrix of long-run coefficients. The equation implies that $Y$ is conditional on dummies. Conditioning on these variables will usually ensure that the system determining $\Delta Y_{t}$ has better stochastic properties in terms of the residuals (Dickey et al. 1994).

The Johansen cointegration tests are shown in Table 3. The results reveal that there is a cointegration relationship between $s-s^{*}$ and $e$ for Hungary, Poland and UK since both maximum eigenvalue and trace tests reject the null of no cointegration ${ }^{7}$.

Given a bivariate model, the Engle-Granger cointegration test is also pursued by regressing $s-s^{*}$ on ex. The results are presented in Table 4 . The test statistics reject the null of no cointegration for Hungary and UK at the $5 \%$ significance level, and for Poland at the $10 \%$ level. The result reinforces the existence of a cointegation relationship found in the Johansen approach.

Evidence of cointegration tends to conflict with the existing empirical literature. For example, the null of no cointegration between stock prices and exchange rates in Bangladesh, India, Pakistan and Sri Lanka is not rejected by Smyth and Nandha (2003). See also Abdalla and Murinde (1997) for Korea and Pakistan. Westermann

\footnotetext{
${ }^{6} \mathrm{~A}$ seasonal dummy variable, which takes the value of one for a given day of the week and zero otherwise, is not considered, because relative stock prices are used here.

${ }^{7}$ In the case of Poland, there is an indication of two cointegration vectors, which implies that the underlying variables are stationary. However, ADF and Phillips Perron's unit root tests, and also the plot of series for Poland, clearly indicate that they are non-stationary.
} 
Table 3. Johansen's Cointegration tests

\begin{tabular}{clrrrr}
\hline $\begin{array}{c}\text { Country } \\
\text { (Order of VAR) }\end{array}$ & Null & \multicolumn{1}{c}{$\lambda_{\max }$} & $95 \% \mathrm{C} . \mathrm{V}$. & $\lambda_{\text {trace }}$ & $95 \% \mathrm{C} . \mathrm{V}$. \\
\hline Hungary (8) & $\mathrm{r}=0$ & $22.611^{*}$ & 19.387 & $31.329^{*}$ & 25.872 \\
& $\mathrm{r}<=1$ & 8.7185 & 12.517 & 8.718 & 12.517 \\
Poland (18) & $\mathrm{r}=0$ & $22.860^{*}$ & 15.494 & $15.735^{*}$ & 14.264 \\
& $\mathrm{r}<=1$ & $7.124^{*}$ & 3.841 & $7.124^{*}$ & 3.841 \\
UK (19) & $\mathrm{r}=0$ & $25.550^{*}$ & 19.387 & $32.258^{*}$ & 25.872 \\
& $\mathrm{r}<=1$ & 6.708 & 12.517 & 6.708 & 12.517 \\
\hline
\end{tabular}

Maximum alternative: $r=1, r=2$ and Trace alternative: $r>=1, r>=2$ against the null $r=0, r<=1$. The Johansen model: 'unrestricted intercept with a linear deterministic trend'.

*Significant at the $5 \%$ level.

The following dummy variables are included in the VAR model specification based on the structural breakpoint tests.

Hungary: dum2000, dum2001, dum2002, dum2003,

Poland: dum2001, dum2002

UK: dum2000, dum2001, dum2002, dum2003

where

Dum2000 : dummy 1 for $1 / 3 / 2000$ onward and dummy 0 otherwise

Dum2001 : dummy 1 for 1/1/2001 onward and dummy 0 otherwise

Dum 2002: dummy 1 for $1 / / 2002$ onward and dummy 0 otherwise

Dum 2003: dummy 1 for 1/1/2003 onward and dummy 0 otherwise

(2004) fails to find a cointegration relationship for stock returns among France, Italy and Germany. This is not surprising given the fact that the cointegration test is conducted over the combined sample period of before and post-euro periods. The failure to obtain the cointegration may be due to the fact that the structural breaks are omitted in their model specification for testing cointegration ${ }^{8}$. It is argued that residual misspecification can arise as a consequence of omitting these conditioning

Table 4. Engle-Granger Cointegration tests

\begin{tabular}{lc}
\hline & $\begin{array}{c}\text { Augmented Engle-Granger } \\
\text { t-statistic }(k)\end{array}$ \\
\hline Hungary & $-4.987(0)$ \\
Poland & $-3.166(5)$ \\
UK & $-3.330(10)$ \\
\hline
\end{tabular}

The t-statistics are obtained by running the following regressions:

$s_{t}-s_{t}^{*}=\alpha+\beta_{0} t+\beta_{1} e x_{t}+\sum_{i=1}^{l} \phi D_{i t}+u_{t} ; \Delta u_{t}=\varphi+\theta u_{t-1}+\sum_{i=1}^{k} \gamma_{i} \Delta u_{t-i}+\varepsilon_{t}$.

The lag lengths $(k)$ are determined by the AIC.

Critical value: 3.25 at the 5\% level with trend (Engle and Yoo, 1987).

$D=$ dummies 
dummy variables (Harris 1995).

The finding of cointegration indicates that permanent shocks affect the relative stock prices and exchange rates in a similar way: common permanent shocks drive their long-term swings, sharing common long-run trends. It also implies that given the relative stock prices, if the exchange rates are fixed, the domestic stock prices move in accord with the German prices, being analogous to a cointegration relationship between the domestic and German stock prices. The existence of cointegration, therefore, suggests that entry to the single currency, which is equivalent to a fixed exchange rate regime, may imply stability in the stock prices for Hungary, Poland and the UK within the EMU. Our results may conflict with the macroeconomic literature, which suggests that a pegged currency can increase economic volatility (Frenkel and Mussa 1980), because there is no longer a fluctuating exchange rate to absorb foreign economic shocks. However, the results are consistent with empirical studies (Artis and Taylor, 1994; Frantianni and von Hagen, 1999), which find that the volatility of domestic economic indicators declines after adoption of the European Monetary system.

The result has an important implication for policy makers, especially in Hungary and Poland. An important component of the ongoing process of establishing financial markets in the transition economies has been the creation of sound stock markets (Poshakwale and Murinde, 2001). These emerging stock markets have undergone privatisation of public enterprises and large numbers of private floatations have taken place. This may have led to volatility in stock markets, and prevented risk averse investors from investing in stock markets. The euro regime may, ceteris paribus, create some stability in the stock market, thereby exerting a beneficial effect on the corporate financial structure for Hungary and Poland.

\section{Long-run Model (cointegration relationship)}

Table 5 presents the cointegrating long-run coefficients based on the EngleGranger methodology with the dummy variables. All coefficients are statistically highly significant with a relatively high goodness of fit. The long-run model suffers from serial correlation, however, the regression is not spurious and the estimates are super-consistent since cointegration is found. Moreover, the principle concern

\footnotetext{
${ }^{8}$ Note, however, that as an extension of the current study, a cointegration test is also conducted for Czech Republic and Slovakia by taking account of structural breaks. It is found that there is no long-run relationship between the relative stock prices and exchange rates.
} 
here is to find the economically reasonable equilibrium relationship of variables in the long-run.

It reveals that depreciation or appreciation of the exchange rate affects the relative stock prices; a negative relationship is found for Hungary and a positive relationship for Poland and the UK.

A negative relationship for Hungary implies that the stock market outperforms the German stock market when the currency appreciates. This, in turn, suggests that currency depreciation has an adverse effect on stock returns. It can be argued that depreciation raises input costs and generates a negative impact on the stock market. This is consistent with the prediction by Malliaropulos (1998) that if changes in exchange rates are positively correlated with inflation, inflation adversely affects company performance, therefore influencing stock prices negatively. The negative relationship may also be explained based on portfolio theory in that depreciation implies a fall in the domestic stock returns against foreign stock returns, hence demand for the domestic shares falls, especially from foreign investors, pushing down the stock prices in Hungary. In terms of

Table 5. Long run model

\begin{tabular}{cccc}
\hline Dependent var. & Hungary $\left(s-s^{*}\right)$ & Poland $\left(s-s^{*}\right)$ & UK $\left(s-s^{*}\right)$ \\
\hline \multirow{2}{*}{ Constant } & $\begin{array}{c}\text { Coefficient } \\
\text { (t-stat. })\end{array}$ & $\begin{array}{c}\text { Coefficient } \\
\text { (t-stat. })\end{array}$ & $\begin{array}{c}\text { Coefficient } \\
\text { (t-stat. })\end{array}$ \\
\hline ex & $15.1864^{*}$ & $1.4989^{*}$ & $0.6742^{*}$ \\
$(22.691)$ & $(23.998)$ & $(22.399)$ \\
dum2000 & $-2.5082^{*}$ & $1.1803^{*}$ & $0.7468^{*}$ \\
dum2001 & $(-20.761)$ & $(26.308)$ & $(10.362)$ \\
dum2002 & $-0.1251^{*}$ & & $-0.1641^{*}$ \\
& $(-11.600)$ & & $(-24.798)$ \\
dum2003 & $-0.3045^{*}$ & $-0.1198^{*}$ & $0.0692^{*}$ \\
time trend & $(-25.028)$ & $(-9.127)$ & $(10.242)$ \\
& $0.1499^{*}$ & $0.2123^{*}$ & $0.1079 *$ \\
Adjusted R-squared & $(11.233)$ & $(20.350)$ & $(12.949)$ \\
Durbin-Watson stat. & $0.3058^{*}$ & & $0.0489^{*}$ \\
\hline
\end{tabular}

Sample period: $1 / 04 / 1999$ to $1 / 26 / 2005$ (1583 observations)

ex $=$ number of domestic currency per Euro

*Significant at the 5\% level. White Heteroskedasticy-consistent S.E. 
magnitude, with $1 \%$ depreciation of exchange rates, the relative stock price falls by $2.5 \%$ for Hungary. This is a relatively large impact in comparison with those of the UK and Poland, suggesting that the above-mentioned effects may be quite strong.

A positive relationship between the two variables for Poland and the UK suggests that the stock markets outperform the German market when the currency depreciates. Economic theory suggests that exchange rate depreciation increases the price competitiveness of export markets, therefore it has a positive effect on firms' performance. By contrast, appreciation creates a comparative disadvantage for domestic firms, which export their products, which may lower their profitability leading to a fall in their stock price. The results for Poland and the UK are in line with these hypotheses.

The almost one for one relationship between $s-s *$ and $e x$ found for Poland (with $1 \%$ depreciation, there is $1.18 \%$ increase in the differential of stock prices) may support the Uncovered Interest Parity (UIP) channel of the relationship, that is, changes in exchange rates cause changes in interest rates, and this, in turn, has an impact on firms' profitability, affecting share prices. Alternatively, the long run equation is, as Malliaropulos (1998) and Morley (2002) suggest, equivalent to directly testing the UIP applied to stock returns and the risk premium. The almost unitary elasticity for Poland implies that the UIP in a stock return version may be supported with the risk premium of 1.49 (i.e. the coefficient on a constant term) with the correct positive sign. This is consistent with the equation (2).

\section{Dynamic Error Correction Models: VAR-GARCH Specification}

Given the existence of cointegration, a natural extension is to model an error correction model. Since the principle concern in this paper is the effect of exchange rates on stock prices for the non-euro zone countries, I focus on the stock price equation. Since modelling the dynamic behaviour of stock prices as a standard VAR model fails to obtain a constant variance of the errors, the VAR-GARCH model is utilised. The regression equation with a GARCH $(1,1)$ is specified as follows:

$$
\Delta\left(s-s^{*}\right)_{t}=\beta_{0, t}+\sum_{i=1}^{p-1} \beta_{i, t} \Delta\left(s-s^{*}\right)_{t-i}+\sum_{i=0}^{p-1} \beta_{i, t} \Delta e x_{t-i}+e c_{t-1}+\psi_{i, t} D_{i, t}+\varepsilon_{t}
$$




$$
\sigma_{t}^{2}=\phi+\mu \varepsilon_{t-1}^{2}+\theta \sigma_{t-1}^{2}
$$

where $p$ is the lag order of VAR. Note that the dependent variable of $\Delta\left(s-s^{*}\right)_{t}$ implies the differential of stock returns between domestic stock returns and German returns (see and Malliaropulos 1998 and Morley 2002). The conditional mean is determined by the lagged values of its own, exchange rates, the last period error correction term $(e c)$ and dummy variables. $\sigma_{t}^{2}$ is the one-period ahead forecast variance based on past information referred to as a conditional variance. The conditional variance depends on the last period's squared residual (the ARCH term) and the last period's conditional variance (the GARCH term). For $\theta=0$, equation becomes the ARCH process and for $\mu=\theta=0$ the variance of daily stock returns is simply a white noise process.

The estimation is conducted from general to specific manner, maintaining significant variables at the level of around $20 \%$. The results of the estimation are reported in Table 6.

Prior to drawing inference from the results, tests on residuals are conducted. The null of linear and non-linear independence of the standardized residuals are tested by the Ljung-Box Q statistic. See Appendix 3 and 4 for the mean and variance equations respectively. The calculated $Q$ values show that up to 30 lags, the

Table 6. Error correction dynamic model: $\operatorname{GARCH}(1,1)$

\begin{tabular}{cccc}
\hline $\begin{array}{c}\text { Hungary }(1577 \text { obs. } \\
\text { dependent variable } \\
\Delta\left(s-s^{*}\right)\end{array}$ & $\begin{array}{c}\text { Variable } \\
(\text { lag })\end{array}$ & coefficient & Z-statistics \\
\hline Mean & $\begin{array}{ccc}{ }^{*}-1 \\
\left(s-s^{*}\right)_{-2}\end{array}$ & $-0.0184^{*}$ & -4.2036 \\
& $\Delta\left(s-s^{*}\right)_{-3}$ & -0.0365 & -1.3695 \\
& $\Delta\left(s-s^{*}\right)_{-5}$ & -0.0271 & -1.0791 \\
& $\Delta e x$ & $-0.2270^{*}$ & -2.5015 \\
& $\Delta e x_{-1}$ & -0.1134 & -2.7832 \\
Variance & $c o n s t a n t$ & 0.0004 & -1.2770 \\
& $\varepsilon_{t-1}^{2}$ & $0.0692^{*}$ & 1.1380 \\
& $\sigma_{t-1}^{2}$ & $0.9125^{*}$ & 5.9337 \\
& constant & $5.5 \mathrm{E}-06^{*}$ & 67.6364 \\
\hline Adjusted R-squared & 0.0190 & Skewness & 2.9908 \\
\hline Durbin-Watson stat. & 2.0834 & Kurtosis & 0.0103 \\
\hline
\end{tabular}


Table 6. Continued.

\begin{tabular}{|c|c|c|c|}
\hline $\begin{array}{c}\text { Poland (1565 obs.) } \\
\text { dependent variable } \\
\qquad \Delta\left(s-s^{*}\right)\end{array}$ & Variable & Coefficient & Z-statistics \\
\hline \multirow[t]{14}{*}{ Mean } & $e c_{-1}$ & $-0.0115^{*}$ & -2.5879 \\
\hline & $\Delta\left(s-s^{*}\right)_{-1}$ & $-0.1038 *$ & -3.9032 \\
\hline & $\Delta\left(s-s^{*}\right)_{-3}$ & -0.0322 & -1.2942 \\
\hline & $\Delta\left(s-s^{*}\right)_{-4}$ & -0.0407 & -1.5724 \\
\hline & $\Delta\left(s-s^{*}\right)_{-5}$ & $-0.0581 *$ & -2.2270 \\
\hline & $\Delta\left(s-s^{*}\right)_{-6}$ & -0.0401 & -1.5565 \\
\hline & $\Delta\left(s-s^{*}\right)_{-13}$ & 0.0317 & 1.2858 \\
\hline & $\Delta\left(s-s^{*}\right)_{-17}$ & $-0.0812 *$ & -3.2468 \\
\hline & $\Delta e x-1$ & $-0.1984 *$ & -3.4351 \\
\hline & $\Delta e x_{-10}$ & $-0.1473 *$ & -2.6463 \\
\hline & $\Delta e x_{-13}$ & 0.0837 & 1.3991 \\
\hline & $\operatorname{dum} 2002$ & $0.0037^{*}$ & 2.1295 \\
\hline & time trend & $-2.55 \mathrm{E}-06$ & -1.3692 \\
\hline & constant & 0.0005 & 0.4846 \\
\hline \multirow[t]{3}{*}{ Variance } & $\varepsilon_{t-1}^{2}$ & $0.0626^{*}$ & 6.4007 \\
\hline & $\sigma_{t-1}^{2}$ & $0.9236^{*}$ & 74.9267 \\
\hline & constant & $4.71 \mathrm{E}-06^{*}$ & 2.7556 \\
\hline Adjusted R-squared & 0.0355 & Skewness & 0.0912 \\
\hline Durbin-Watson & 2.0201 & Kurtosis & 3.6713 \\
\hline
\end{tabular}

standardized residuals are statistically insignificant, not rejecting the null. This suggests that the standard GARCH $(1,1)$ model is appropriate for the current study ${ }^{9}$. The normality of the standardized residuals may be measured by the skewness and kurtosis diagnostics. The normal distribution requires that the skewness be zero and the kurtosis three. The results appear to demonstrate the normal distribution of residuals.

Parameter values in the variance equations are highly significant, confirming the presence of significant heteroscedasticiy representing time-varying stock return volatility. This suggests that current volatility is a function of last period's squared

\footnotetext{
${ }^{9}$ The ARCH-M model is often used in stock returns where the expected return on an asset is related to the expected asset risk. Given the empirical evidence that there is no relationship between conditional volatility and expected returns for Hungary and Poland (Poshakwale and Murinde, 2001), this is not considered here.
} 
Table 6. Continued.

\begin{tabular}{|c|c|c|c|}
\hline $\begin{array}{c}\text { UK (1564 obs.) } \\
\text { dependent variable } \\
\Delta\left(s-s^{*}\right)\end{array}$ & Variable & coefficient & Z-statistics \\
\hline \multirow[t]{13}{*}{ Mean } & $e c_{-1}$ & $-0.0174 *$ & -4.4279 \\
\hline & $\Delta\left(s-s^{*}\right)_{-1}$ & $-0.0848 *$ & -3.3559 \\
\hline & $\Delta\left(s-s^{*}\right)_{-2}$ & 0.0407 & 1.5386 \\
\hline & $\Delta\left(s-s^{*}\right)_{-6}$ & 0.0449 & 1.7772 \\
\hline & $\Delta\left(s-s^{*}\right)_{-10}$ & $-0.0719 *$ & -2.7870 \\
\hline & $\Delta\left(s-s^{*}\right)_{-14}$ & $0.0634 *$ & 2.4748 \\
\hline & $\Delta\left(s-s^{*}\right)_{-15}$ & -0.0357 & -1.4396 \\
\hline & $\Delta\left(s-s^{*}\right)_{-18}$ & $0.0759 *$ & 3.0531 \\
\hline & $\Delta e x$ & $0.2222 *$ & 4.6642 \\
\hline & $\Delta e x_{-6}$ & -0.0597 & -1.2894 \\
\hline & $\Delta e x_{-11}$ & 0.0691 & 1.6976 \\
\hline & $\Delta e x_{-15}$ & 0.0664 & 1.4865 \\
\hline & constant & -0.0004 & -1.6943 \\
\hline \multirow[t]{3}{*}{ Variance } & $\varepsilon_{t-1}^{2}$ & $0.0643 *$ & 7.6178 \\
\hline & $\sigma_{t-1}^{2}$ & $0.9354^{*}$ & 111.8085 \\
\hline & constant & $2.74 \mathrm{E}-07$ & 1.2805 \\
\hline Adjusted R-squared & 0.0385 & Skewness & 0.0669 \\
\hline Durbin-Watson stat & 2.0559 & Kurtosis & 4.0132 \\
\hline
\end{tabular}

*Significant at the $5 \%$ level.

innovations and volatility. The estimated coefficients imply that the conditional variance is updated in the light of new information and the weight of the last squared innovation is equal to $0.069,0.062$ and 0.064 respectively (Koutmos, 1997). The GARCH terms, being around 0.91, 0.92 and 0.93, are larger than those of Westermann's for France, Germany and Italy being 0.78, 0.84 and 0.63 respectively in the post-euro period. In all cases, the sum of the ARCH and GARCH coefficients is very close to one, suggesting that the ARCH model is integrated in variance and equivalent to a unit root in conditional means (Poshakwale and Murinde, 2001). Note that in the GARCH procedure, shocks to the current volatility of stock returns is persistent if $\mu+\theta=1$. The result, therefore, implies that the return generating process is characterised by a high degree of persistence in conditional variance, and that the effects of volatility shocks can be 
quite persistent. Although this is often found in high-frequency daily financial data, the larger GARCH terms than those in France, Germany and Italy suggest that the persistency of shocks may be stronger in the stock markets in Hungary, Poland and the UK than that in the euro-zone.

The error correction term $(e c)$ is highly significant with the correct sign of negative. Given estimated coefficients of 0.018 for Hungary, 0.011 for Poland and 0.017 for the UK, it implies that it takes about 55, 90 and 59 days respectively to reach the long-run level. Poland lags behind Hungary and the UK.

A level feedback from exchange rates to the stock return differentials is observed in Hungary and the UK. The sign is consistent with those in the long run model. The positive relationship for the UK is in line with the study by Morley (2002), who finds a positive relationship between stock return differentials and the exchange rates against the US dollar.

The martingale hypothesis suggests that changes in stock prices from period $t-1$ to period $t$ are innovations, which are orthogonal to the previously available information. In the case of our model, under the null hypothesis that the stock return differential is independent of the previously available information, parameters $\beta_{t}$ should be zero. Significant effects from the lagged dependent variable are, however, observed in all three cases, implying that the hypothesis is rejected. This is consistent with the findings for the UK by Koutmos (1997) and for Poland and Hungary by Poshakwale and Murinde (2001) in their study of the stock returns. In the UK and Poland, the negative effect from $\Delta\left(s-s^{*}\right)_{-1}$ is highly significant. This implies that if the domestic stock return is higher than the German stock return, the domestic return falls on the following day, exhibiting an adjustment effect.

The influence of the lagged exchange rates on the dependent variables in the UK (though statistically significant at a lower level) is consistent with the study of Ajayi et al. (1998), who find a causality from exchange rates to stock prices for the UK over the sample period of 1985 to 1991 using daily data.

The effects of $\Delta e x$ for Hungary and $\Delta e x_{-1}$ and $\Delta e x_{-10}$ for Poland are negative being statistically significant at the $5 \%$ level. This indicates that currency depreciation will drag down the stock returns in Poland and Hungary against those in Germany within 10 days. This may reflect international investors' portfolio behaviour moving away from investing in the stock market where there are exchange rate risks. This is, perhaps, compared with that of UK, where there is a no significant negative effect from the lagged exchange rate at the $5 \%$ level. In this 
sense, the results from the dynamic model illustrate that perception of the exchange rate risk may be stronger in the emerging stock market than that in the developed stock market.

\section{Conclusion}

This paper aims to investigate the effect of the euro on the stock markets of Hungary, Poland and the UK, coupled with the co-movement of stock prices against that of Germany using the daily stock market indices. The Johansen and Engle-Granger tests indicate that there is a cointegration relationship between the relative stock prices and exchange rates. The dynamic error correction model is captured by the GARCH models, suggesting that nonlinearity caused by shocks is reflected in the heteroskedastic behaviour. The overall estimated coefficients are quite plausible both in the long and short run. The behaviour of the stock markets in the transition economies of Hungary and Poland does not appear to be much different from that of a developed economy such as the UK, except that there is some evidence of difference in risk perception in stock markets and foreign exchange markets in the short-run.

Evidence highlights that the euro influences the stock markets of these non eurozone economies. Respective policy makers should be, therefore, cautious in the conduct of exchange rate policies, given that such policies may have ramifications on their stock markets (Abdalla and Murinde, 1997). In particular, it is found that the Hungarian stock market outperforms the German stock market when the currency appreciates, whereas the Polish stock market outperforms when the currency depreciates. These results imply that for the development of emerging stock markets, in order to stimulate equity finance for the corporate sector, appreciation of exchange rates may be an appropriate policy for Hungary, versus that of depreciation for Poland. The finding of a cointegration relationship between the domestic stock prices relative to German stock prices and exchange rates suggests that entry to the EMU may, ceteris paribus, lead to stabilise the stock markets for Hungary, Poland and UK.

This paper sheds light on the study of the co-movements of stock prices and exchange rates for the non-euro zone against the euro-zone. As the EU enlarges in future, an extensive further research would be useful in order to determine the relationship in additional countries. 


\section{Acknowledgments}

I would like to thank the participants of the 4th Annual Conference of the European Economics and Finance Society, 'Economic and Financial Issues in an Enlarged Europe', held at the University of Coimbra in May 2005 for their useful comments.

Received 16 May 2005, Accepted 31 July 2006

\section{References}

Abdalla, Issam S.A. and Victor Murinde (1997). Exchange rate and stock price interactions in emerging financial markets: evidence of India, Korea, Pakistan and the Philippines, Applied Financial Economics, 7, 25-35.

Ajayi, Richard A., Joseph Friedman and Seyed M. Mehdian (1998) On the relationship between stock returns and exchange rates: tests of Granger causality, Global finance Journal, 9, 241-251.

Artis, M.J. and M.P. Taylor (1994) The stabilizing effect of the ERM on exchange rates and interest rates, International Monetary Fund Staff Papers, 41, 123-148.

Bahmani-Oskooee, Mohsen, and Sohrabian, Ahmad. (1992) Stock prices and the effective exchange rate of the dollar, Applied Economics, 24(4), 459-464.

Bai, J. (1996). Estimation of a change Point in Multiple Regression Model, Review of Economics and Statistics, Vol. 79, pp.551-563.

Baily, Warren, Connie X. Mao and Rui Zhong (2003) Exchange rate regimes and stock return volatility: some evidence from Asia's silver era, Journal of Economics and business, 55, 557-584.

Dickey, D.A., D.W. Jansen and D.L. Thornton (1994). A Primer on Cointegration with an Application to Money and Income, in ed. Rao, B.B., Cointegration for the Applied Economist, St. Martin's Press, Inc.

Engle, R.F. and B.S. Yoo (1987). Forecasting and testing in co-integrated systems, Journal of Econometrics, 35, 143-159.

Fratianni, M. and J. von Hagen (1990) The European monetary system ten years after, Carnegie-Rochester Conference Series on Pubic Policy, 32, 173-242.

Frenkel, J.A., and M.L. Mussa (1980) The efficiency of foreign exchange markets and measures of turbulence, American Economi Association Papers and Proceedings, 70, 374-381.

Granger, Clive W.J., Bwo-Nung Huang and Chin-Wei Yang (2000) A bivariate causality between stock prices and exchange rates: evidence from recent Asian flu, Quarterly review of Economics and Finance, 40, 337-354.

Malliaropulos, Demitrios (1998). International stock return differentials and real exchange 
rate changes, Journal of International Money and finance, 17, 493-511.

Hansen Bruce E. (2001) The New Econometrics of Structural Change: dating Breaks in U.S. Labor Productivity, Journal of Economic Perspectives, 154 (Fall), 117-128.

Harris, Richard (1995). Cointegration Analysis in Econometric Modelling, Prentice Hall. Hayashi, F. (2000). Econometrics, Princeton, Princeton University Press.

Perron, P. (1989). The Great Crash, the Oil Price Shock, and the Unit Root Hypothesis, Econometrica, 57 (6) 1361-1401.

Richard, A. (1995). Co-movements in national stock market returns: evidence of predictability, but not cointegration, Journal of Monetary Economics, 36, 631-654.

Koutmos, Gregory (1992) Feedback trading and the autocorrelation pattern of stock returns: further empirical evidence, Journal of International Money and Finance, 16, 625-636.

Morley, Bruce (2002) Exchange rates and stock prices: implications for European convergence, Journal of Policy Modelling, 24, 523-526.

Nieh, Chien-Chung and Cheng-Few Lee (2001) Dynamic relationship between stock prices and exchange rates for G7 countries, Quarterly Review of Economics and Finance, 41, 477-490.

Poshakwale, Sunil and Victor Murinde (2001) Modelling the volatility in East Europena emerging stock markets: evidence on Hungary and Poland, Applied Financial Economics, 11, 445-456.

Ratner Mitchell (1993) A Cointegration test of the impact of foreign exchange rates on US stock market prices, Global Finance Journal, 4(2), 93-101.

Ragunathan, V., R.W. Faff and R.D. Brooks (1999) Correlations, business cycles and integration, Journal of International Financial Markets Institutions and Money, 9, 75-95.

Shamsuddin, Abul, F.M. and Jae H. Kim (2003) Integration and interdependence of stock and foreign exchange markets: an Australian perspective, International Financial markets, Institutions and Money, 13, 237-254.

Smyth, R. and M. Nandha (2003). Bivariate causality between exchange rates and stock prices in South Asia, Applied Economics Letters, 10, 699-704.

Westermann, France (2004) Does the Euro affect the dynamic interactions of stock markets in Europe? Evidence from France, Germany and Italy, The European journal of Finance, 10, April, 139-148.

\section{Appendix 1}

Plot of the series: $s-s^{*}$ and $e x$ in levels $\left(S-s^{*}\right)$ differential of stock price indices 
ex: number of domestic currency per unit of euro

all in logarithm
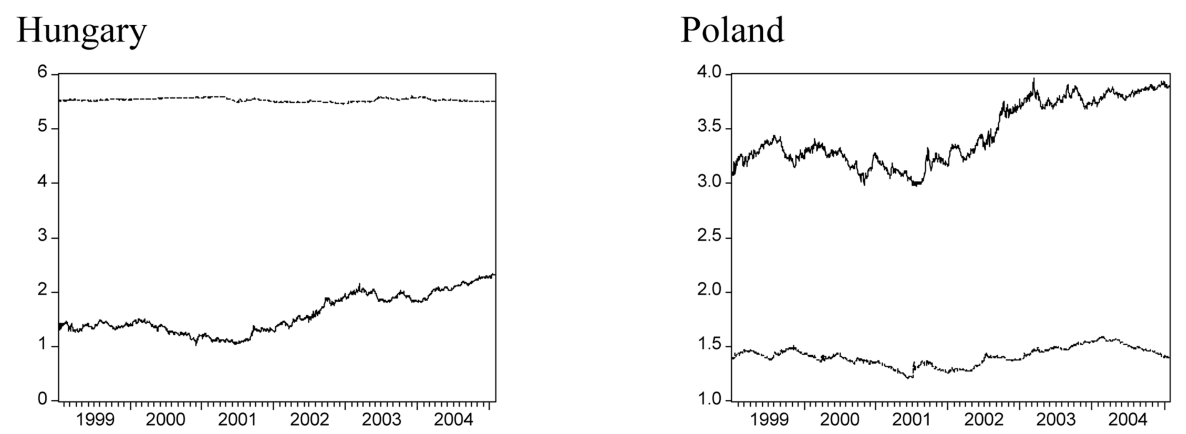

UK

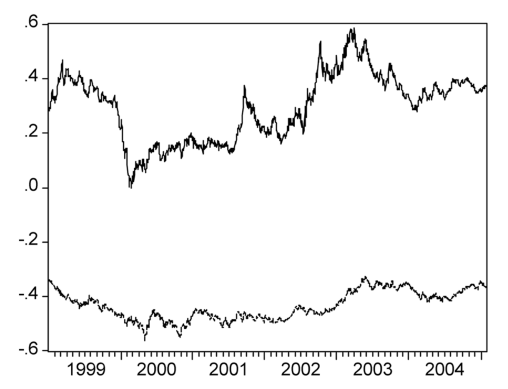

\section{Appendix 2}

Plot of the series: $s-s^{*}$ and $e x$ in first differences

\section{Appendix 3}

GARCH $(1,1)$ Model: Ljung-Box Q statistics for the mean equation

Poland $\left(s-s^{*}\right)$

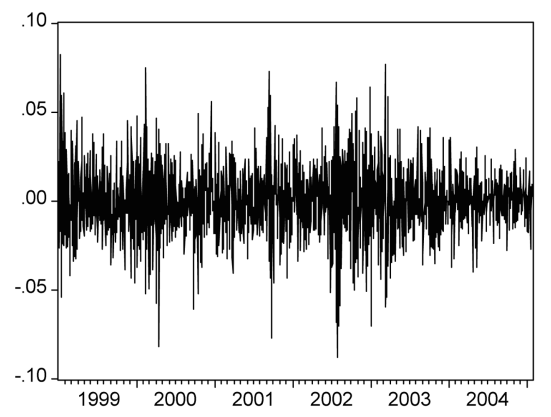

Poland (ex)

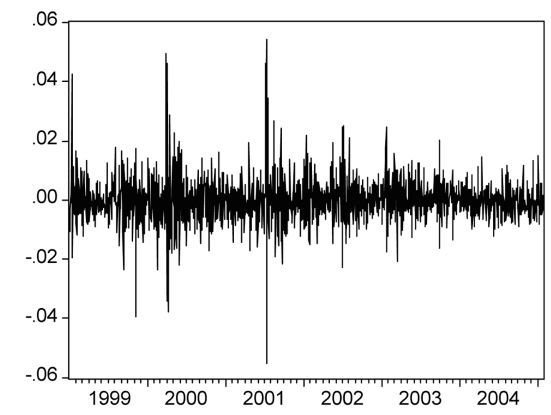


Hungary $\left(s-s^{*}\right)$

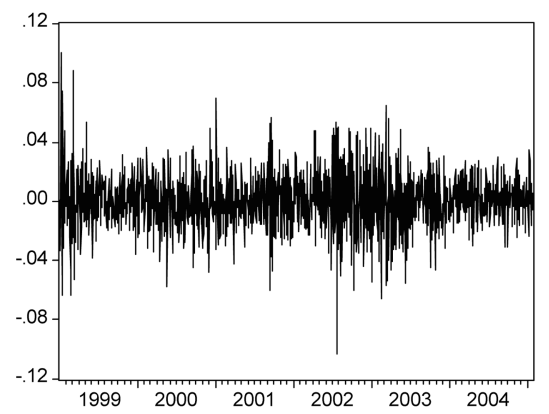

UK $\left(s-s^{*}\right)$

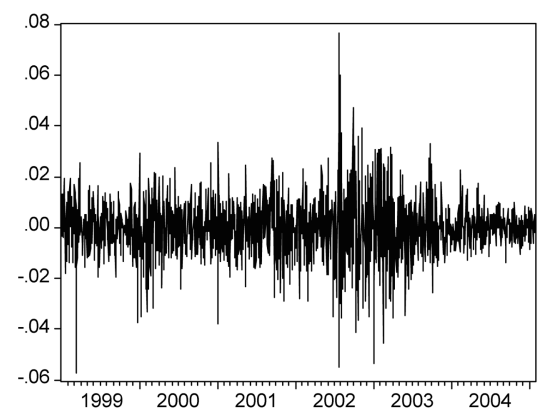

Hungary (ex)

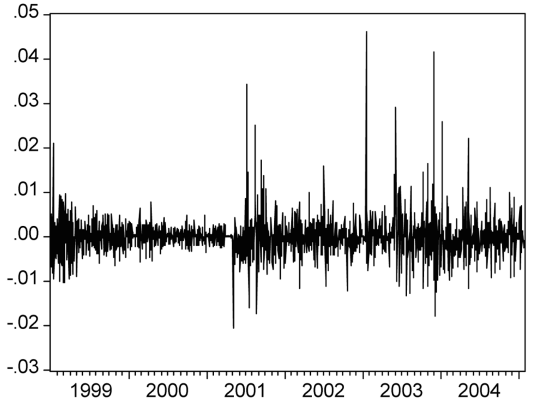

UK (ex)

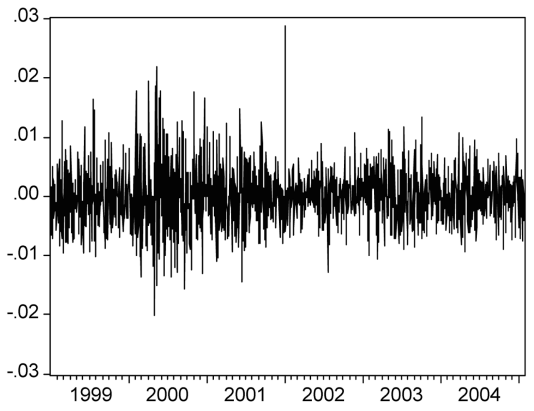

\begin{tabular}{ccccccc}
\hline & Hungary & \multicolumn{3}{c}{ Poland } & UK \\
lag & Q-Stat & Prob & Q-Stat & Prob & Q-Stat & Prob \\
\hline 1 & 0.1578 & 0.6910 & 0.1888 & 0.6640 & 0.4226 & 0.5160 \\
2 & 0.1852 & 0.9120 & 0.3651 & 0.8330 & 0.4280 & 0.8070 \\
3 & 0.2099 & 0.9760 & 0.4857 & 0.9220 & 0.5121 & 0.9160 \\
4 & 0.2223 & 0.9940 & 0.7954 & 0.9390 & 0.5127 & 0.9720 \\
5 & 0.2642 & 0.9980 & 1.0162 & 0.9610 & 0.6419 & 0.9860 \\
10 & 1.1611 & 1.0000 & 1.4805 & 0.9990 & 1.6532 & 0.9980 \\
15 & 6.8974 & 0.9600 & 4.7956 & 0.9940 & 5.2678 & 0.9900 \\
20 & 20.4380 & 0.4310 & 6.7999 & 0.9970 & 5.8696 & 0.9990 \\
25 & 26.8850 & 0.3620 & 8.6633 & 0.9990 & 7.2546 & 1.0000 \\
30 & 32.1650 & 0.3600 & 13.5970 & 0.9960 & 11.1490 & 0.9990 \\
\hline
\end{tabular}




\section{Appendix 4}

GARCH $(1,1)$ Model: Ljung-Box Q statistics for the variance equation

\begin{tabular}{|c|c|c|c|c|c|c|}
\hline \multicolumn{3}{|c|}{ Hungary } & \multirow{2}{*}{$\begin{array}{l}\text { Poland } \\
\text { Q-Stat }\end{array}$} & \multicolumn{3}{|c|}{ UK } \\
\hline lag & Q-Stat & Prob & & Prob & Q-Stat & Prob \\
\hline 1 & 1.2951 & 0.2550 & 0.4271 & 0.5130 & 2.6723 & 0.1020 \\
\hline 2 & 2.3903 & 0.3030 & 0.4272 & 0.8080 & 2.7220 & 0.2560 \\
\hline 3 & 7.0958 & 0.0690 & 3.1102 & 0.3750 & 3.5435 & 0.3150 \\
\hline 4 & 7.1173 & 0.1300 & 3.6736 & 0.4520 & 3.7632 & 0.4390 \\
\hline 5 & 7.4150 & 0.1920 & 4.0498 & 0.5420 & 3.8133 & 0.5770 \\
\hline 10 & 11.1730 & 0.3440 & 12.9540 & 0.2260 & 5.9027 & 0.8230 \\
\hline 15 & 13.8970 & 0.5330 & 16.6290 & 0.3420 & 14.8560 & 0.4620 \\
\hline 20 & 20.0370 & 0.4560 & 20.8500 & 0.4060 & 23.3430 & 0.2720 \\
\hline 25 & 23.2800 & 0.5610 & 21.6250 & 0.6570 & 31.3700 & 0.1770 \\
\hline 30 & 26.5820 & 0.6450 & 24.5490 & 0.7470 & 36.5040 & 0.1920 \\
\hline
\end{tabular}

